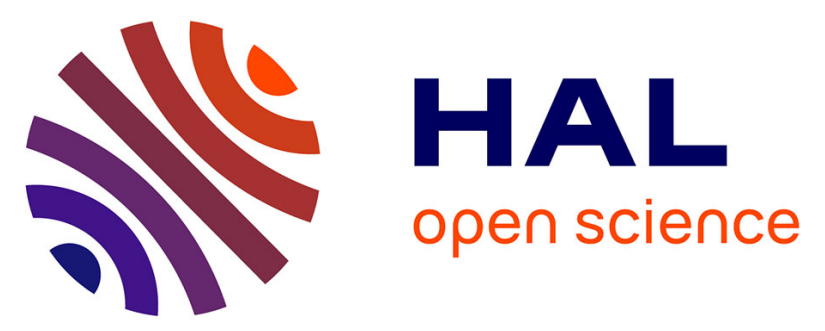

\title{
A therapeutic oxygen carrier isolated from Arenicola marina decreases amanitin-induced hepatotoxicity
}

Brendan Le Daré, Pierre-Jean Ferron, Nessrine Bellamri, Catherine Ribault, Eric Delpy, Franck Zal, Vincent Lagente, Thomas Gicquel

\section{- To cite this version:}

Brendan Le Daré, Pierre-Jean Ferron, Nessrine Bellamri, Catherine Ribault, Eric Delpy, et al.. A therapeutic oxygen carrier isolated from Arenicola marina decreases amanitin-induced hepatotoxicity. Toxicon, 2021, 200, pp.87-91. 10.1016/j.toxicon.2021.07.004 . hal-03334103

\section{HAL Id: hal-03334103 https://hal.science/hal-03334103}

Submitted on 18 Oct 2021

HAL is a multi-disciplinary open access archive for the deposit and dissemination of scientific research documents, whether they are published or not. The documents may come from teaching and research institutions in France or abroad, or from public or private research centers.
L'archive ouverte pluridisciplinaire HAL, est destinée au dépôt et à la diffusion de documents scientifiques de niveau recherche, publiés ou non, émanant des établissements d'enseignement et de recherche français ou étrangers, des laboratoires publics ou privés. 


\section{Contributors}

All authors contributed significantly, and all authors agree with the content of the manuscript: Conception/Design: Brendan Le Daré, Thomas Gicquel, Vincent Lagente

Collection and/or assembly of data: Brendan Le Daré, Thomas Gicquel, Vincent Lagente, Nessrine Bellamri, Pierre-Jean Ferron, Catherine Ribault

Data analysis and interpretation: All authors

Manuscript writing: All authors

Final approval of manuscript: All authors. 


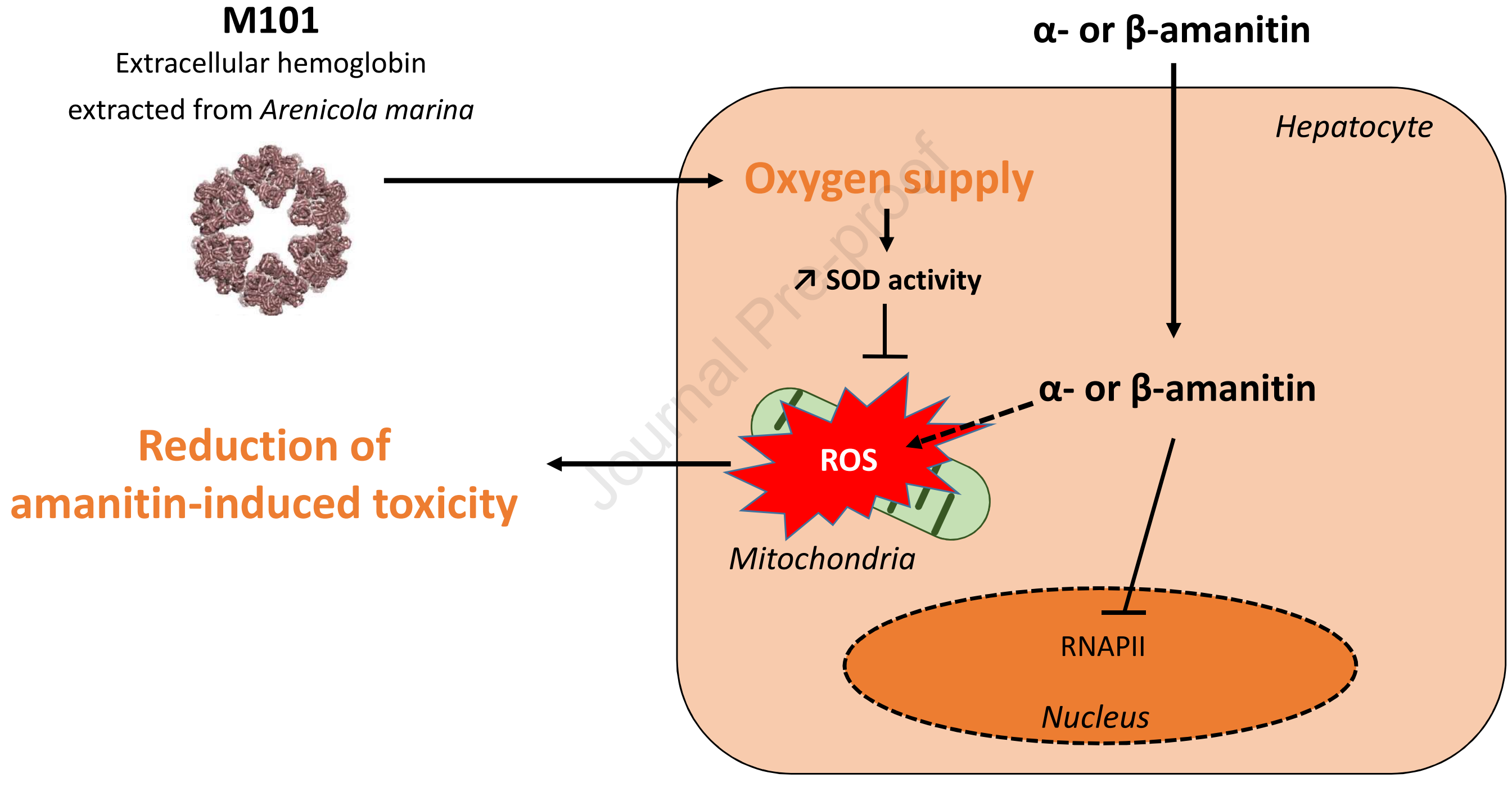


1

Short communication

2 A therapeutic oxygen carrier isolated from Arenicola marina decreases amanitin-

3 induced hepatotoxicity

4 Brendan Le Daré ${ }^{1,2}$, Pierre-Jean Ferron ${ }^{2}$, Nessrine Bellamri² ${ }^{2}$ Catherine Ribault ${ }^{2}$, Eric Delpy ${ }^{3}$, Franck

$5 \mathrm{Zal}^{3}$, Vincent Lagente ${ }^{2}$, Thomas Gicquel ${ }^{1,2}$

6

7 1: Forensic and Toxicology Laboratory, Pontchaillou University Hospital, F-35000, Rennes, France

8

$9 \quad$ Rennes, France

10 3: Hemarina, Aéropôle centre, F-29600 Morlaix, France.

11

Corresponding author: Dr. Brendan Le Daré (ORCID: 0000-0002-5907-2450 and Publons: AAL7050-2020)

Address: Laboratoire de toxicologie biologique et médico-légale, CHU Pontchaillou, 2 Rue Henri Le Guilloux, F-35000 Rennes, France.

E-mail: brendan.le.dare@chu-rennes.fr

8




\section{ABSTRACT}

26

27 28

29

30

3

.

The amanitins (namely $\alpha$ - and $\beta$-amanitin) contained in certain mushrooms are bicyclic octapeptides that, when ingested, are responsible for potentially lethal hepatotoxicity. M101 is an extracellular hemoglobin extracted from the marine worm Arenicola marina. It has intrinsic Cu/Zn-SOD-like activity and is currently used as an oxygen carrier in organ preservation solutions. Our present results suggest that M101 might be effective in reducing amanitin-induced hepatotoxicity and may have potential for therapeutic development.

KEYWORDS: amanitin, oxygen carrier, M101, hepatocyte, hepatotoxicity 


\section{INTRODUCTION}

Amanitins are high-molecular-weight bicyclic octapeptides present in certain mushrooms. When ingested, these compounds are responsible for potentially lethal hepatotoxicity. The best-characterized amanitins are $\alpha$-amanitin and $\beta$ - amanitin because they are present at high levels in the mushrooms involved in poisonings (Kaya et al., 2013). After amanitin accumulation in the liver via uptake through the organic anion transporter OATP1B3 in the hepatocyte's sinusoidal membrane (Letschert et al., 2006), the compounds inhibit the RNA polymerase II in the nucleus and thus jeopardize mRNA translation and protein synthesis (Wieland, 2009). The amanitin-induced stress signal has been shown to induce p53 protein, which then forms complexes with protective proteins ( $\mathrm{Bcl}-\mathrm{X}_{\mathrm{L}}$ and $\left.\mathrm{Bcl}-2\right)$ and subsequent triggers apoptosis via release of mitochondrial cytochrome c into the cytosol (Arima et al., 2005; Leu and George, 2007; Ljungman et al., 1999). Accordingly, Wang et al. (2018) showed that $\alpha$ amanitin induces significant changes in the mitochondrial proteome and might destroy the mitochondrial membrane potential (Wang et al., 2018). It has also been suggested that oxidative stress is important in the development of severe hepatotoxicity, since $\alpha$-amanitin accumulation leads to an increase in the activity of superoxide dismutase (SOD) and glutathione peroxidase, the production of malondialdehyde, and lipid peroxidation, and inhibits catalase activity (DüNdar et al., 2017; Zheleva et al., 2007). Furthermore, it has been reported that $\alpha$-amanitin forms phenoxyl free radicals that might be involved in the production of reactive oxygen species (ROS) (Zheleva, 2013). Interestingly, most effective antidotes (including $\mathrm{N}$-acetylcysteine, silymarin and silibinin) have antioxidant properties (Magdalan et al., 2011; Tavassoli et al., 2019; Ye and Liu, 2018). Thus, avoiding oxidative stress appears to be the most promising treatment option.

M101 is an extracellular hemoglobin extracted from the marine worm Arenicola marina. It is currently used in medicine as an oxygen carrier in organ preservation solutions. This class III medical device (commercialized as $\mathrm{HEMO}_{2} \mathrm{life}^{\circledR}$ by Hemarina, Morlaix, France) was found to improve the preservation of kidney grafts (Mallet et al., 2014; Thuillier et al., 2019), hearts (Teh et al., 2017) lungs (Ali et al., 2020; Glorion et al., 2017) and liver transplants (Alix et al., 2020) in vivo. Furthermore, in vitro studies have demonstrated that M101's intrinsic Cu/Zn-SOD-like activity can protect against the damage potentially caused by ROS release (Lemaire et al., 2019; Rousselot et al., 2006; Thuillier et al., 
its therapeutic development. In this context, the objective of the present study was to evaluate M101's effect on the putative mechanisms of amanitin-induced hepatotoxicity and thus its potential for therapeutic development.

\section{MATERIAL AND METHODS}

2.1 Reagents: Phosphate-buffered saline (PBS), Williams's E medium, Hanks' balanced salt solution (HBSS), penicillin-streptomycin, and L-glutamine were purchased from Life Technologies (Eugene, OR, USA). Fetal calf serum (FCS) was obtained from Hyclone (Logan, UT, USA). Insulin, hydrocortisone, $\alpha$ - and $\beta$-amanitin, SOD inhibitors (diethylthiocarbamic acid [DETC] and 1,4,5dichloro-2-m-tolylpyridazin-3(2H)-one [LCS]) and SOD assay kit were from Sigma Aldrich (St. Louis, MO, USA). The luminescent ATP detection assay kit was purchased from Abcam (Cambridge, MA, USA). MitoSOX red mitochondrial superoxide indicator was from ThermoFisher Scientific (Waltham, MA, USA). M101 $\left(\mathrm{HEMO}_{2}\right.$ life $\left.^{\circledR}\right)$ was provided by Hemarina as a frozen stock solution $(50 \mathrm{~g} / \mathrm{L})$ and used in these experiments at a final concentration in culture medium of $1 \mathrm{~g} / \mathrm{L}$ (the concentration used in organ preservation solutions). Carboxy-M101 (M101-CO) was obtained by bubbling carbon monoxide gas $99.997 \%$ (Rapid'Gaz, Verdun, France) for 10 minutes in the M101 solution.

2.2 Cell cultures: Progenitor HepaRG cells were cultured as described elsewhere (Aninat et al., 2006). Briefly, the cells were seeded at a density of $2.6 \times 10^{4} / \mathrm{cm}^{2}$ in 96 -well plates in William's E medium supplemented with $10 \%$ FBS, $50 \mathrm{U} / \mathrm{mL}$ penicillin, $50 \mu \mathrm{g} / \mathrm{mL}$ streptomycin, $5 \mu \mathrm{g} / \mathrm{mL}$ insulin, $2 \mathrm{mM}$ glutamine, and $50 \mu \mathrm{M}$ sodium hydrocortisone hemisuccinate. After two weeks, cells were cultured for a further two weeks in the same medium supplemented with $2 \%$ DMSO in order to promote hepatocyte differentiation into both cholangiocyte- and hepatocyte-like cells (Cerec et al., 2007).

2.3 Measurement of amanitin-induced mitochondrial stress: MitoSOX Red Mitochondrial Superoxide Indicator (ThermoFisher Scientific, MA, USA) was used to measure mitochondrial ROS production. Briefly, cells were incubated in the dark with $100 \mu \mathrm{L}$ of MitoSOX $(5 \mu \mathrm{M})$ probes for 30 minutes at $37^{\circ} \mathrm{C}$ and with $5 \% \mathrm{CO}_{2}$. After the required incubation time, the medium was removed and the cells were washed once with $100 \mu \mathrm{L}$ of HBSS at room temperature. The wells were then read quickly using a 
fluorescence microplate reader (POLARstar Omega ${ }^{\circledR}$, BMG labtech, Ortenberg, Germany), and the data were analyzed using MARS software (BMG labtech). The results were normalized for the protein concentration assay (determined with a Pierce ${ }^{\mathrm{TM}}$ BCA protein assay Kit, (ThermoFisher Scientific).

2.4 Cell viability: Cytotoxicity was assessed using a Luminescent ATP Detection Assay Kit (Abcam), according to the manufacturer's instructions. Plates were read using a microplate reader (POLARstar Omega $^{\circledR}$, BMG labtech).

2.5 SOD activity measurement: SOD activity was assessed using SOD assay kit (Sigma Aldrich, St. Louis, MO, USA) according to the manufacturer's instructions. HepaRG cell lysis was performed with RIPA buffer (Sigma Aldrich) and SOD activity was evaluated in $40 \mu \mathrm{l}$ of cell lysate.

2.6 Statistical analysis: Data were expressed as the mean \pm standard error of the mean (SEM). Intergroup differences as a function of the treatment were probed in a one-way analysis of variance (ANOVA), with a Bonferroni post hoc test for group comparisons. All analyses were performed using Prism software (version 5.0, GraphPad Software, La Jolla, CA, USA). All tests were two-sided, and the threshold for statistical significance was set to $p<0.05$. Differences between $\alpha$ - and $\beta$-amanitin were probed in a two-way ANOVA, with a bonferroni post hoc test.

\section{RESULTS}

Since amanitin exposure is known to be hepatotoxic, we looked at whether these toxins were able to dose-dependently decrease viability in a cell-based model of the liver (i.e. differentiated HepaRG cells). We found that amanitin significantly decreased the viability of differentiated HepaRG cells in a dosedependent manner, starting at $1 \mu \mathrm{M}$ - showing that the model was sensitive (Figure 1A). $\alpha$-amanitin was more potent than $\beta$-amanitin in terms of loss of viability at $1 \mu \mathrm{M}$, but not at other concentrations. Furthermore, we observed that $\alpha$ - or $\beta$-amanitin increased mitochondrial ROS generation in a dosedependent manner, starting at $2 \mu \mathrm{M}$. Mitochondrial ROS production was also higher with $\alpha$-amanitin compared to $\beta$-amanitin at $2 \mu \mathrm{M}(p<0.05)$, but not at other concentrations. Taken together, these results 
indicate that the amanitins' toxic effect on differentiated HepaRG cells is dependent - at least in part on mitochondrial ROS production.

In order to investigate M101's effect on amanitin-induced toxicity, all subsequent experiments were performed with the concentration of $\alpha$ - and $\beta$-amanitin $(2 \mu \mathrm{M})$ that reduced the viability of differentiated HepaRG cells by $50 \%$ and induced significant mitochondrial oxidative stress. M101 ( $1 \mathrm{~g} / \mathrm{L})$ was added at the same time as amanitins (H0), $1 \mathrm{~h}$ after amanitins (H1), $3 \mathrm{~h}$ after amanitins (H3) or $6 \mathrm{~h}$ after amanitins (H6). Under all conditions, M101 remained incubated along with amanitins. We found that M101 alone (1 g/L) significantly increased cell viability. We observed that after $24 \mathrm{~h}$ of exposure to amanitin, cell viability was significantly higher in the presence of M101 $(1 \mathrm{~g} / \mathrm{L})$ when added up to $6 \mathrm{~h}$ after $\beta$-amanitin (H6) and up to $3 \mathrm{~h}$ after $\alpha$-amanitin (H3) (Figure $2 \mathrm{~A}$ ). This effect was associated with a significantly lower level of mitochondrial ROS generation in the presence of M101 (1 g/L) when added at the same time as $\alpha$-amanitin (H0) and up to $6 \mathrm{~h}$ after $\beta$-amanitin (H6) (Figure 2B). M101 resulted in an increase in cell viability as well as a greater decrease in ROS production with $\beta$-amanitin than with $\alpha$-amanitin. Taken together, these results show that M101 protects a cell-based hepatic model against amanitin's toxicity. Furthermore, M101 had a protective effect of the cells even when added several hours after amanitin.

Since M101 is capable of delivering oxygen to the surrounding environment, we aimed to evaluate whether M101 without its oxygen carrier proprieties (M101-CO) impacted intracellular SOD activity. HepaRG cells were incubated with M101 (1 g/L) or M101-CO (1 g/L) with or without SOD1 inhibitors (DETC $100 \mu \mathrm{M}$ or LCS $10 \mu \mathrm{M}$ ) (Figure 2C). We found that M101 was able to increase intracellular SOD activity $(p<0.01)$, even in the presence of DETC $(p<0.01)$. Similar trend was observed using LCS without reaching statistical significance. This effect was no longer present using M101-CO (Figure 2C). Interestingly, none of these conditions resulted in cell death (Figure 2D).

\section{DISCUSSION}

In this study, we found that a therapeutic oxygen carrier isolated from Arenicola marina (M101) had protective effect on amanitin-induced toxicity on in vitro hepatic cell model. We first evaluated the amanitins' toxicity on differentiated HepaRG cells in vitro; we observed a dose-dependent decrease in cell viability and a concomitant elevation in mitochondrial ROS generation, starting at an amanitin 
concentration of $2 \mu \mathrm{M}$. Therefore, this $2 \mu \mathrm{M}$ dose was particularly relevant for testing the efficacy of an antidote on these two parameters. These results are in line with the literature data on the involvement of oxidative stress in amanitin toxicity (DüNdar et al., 2017; Zheleva, 2013; Zheleva et al., 2007). Our study showed that differentiated HepaRG cells constitute a sensitive, reproducible model for studying the toxicity of amanitin. We found that M101 alone significantly increased cell viability, probably because M101 has oxygen-carrier properties, resulting in increased mitochondrial activity. Interestingly, M101 was able to restore HepaRG cell viability and decrease mitochondrial ROS generation after $\alpha$ and $\beta$-amanitin exposure. However, it is unknown whether a change in cell viability was due to an increase in ROS production or the changes in ROS was due to reduced viability. Moreover, we showed that the cells' ROS production was greater after $\alpha$-amanitin exposure than after $\beta$-amanitin exposure. This might explain why (i) M101 had a greater effect on $\beta$-amanitin-induced effects and (ii) cell viability was even restored when M101 was added several hours after the toxin. Given that $\alpha$-and $\beta$-amanitin are neutral and acid compounds, one can reasonably hypothesize that the differing responses to M101 are related to the toxins' physical-chemical properties (Garcia et al., 2015). Considering M101's macrostructure ( $3600 \mathrm{kDa}, 15 \mathrm{x} 25 \mathrm{~nm}$ ), this hemoglobin is unlikely to enter hepatocytes. However, we hypothesize that M101's oxygen-carrier properties might be partially responsible for the beneficial effect observed in vitro. Using M101-CO, which allowed us to observe the effects of M101 without its oxygen-carrier properties (G. Tsai et al., 2012), we showed that M101 lost its intracellular SOD activating effect. Thus, although the precise mechanisms are not elucidated, these results suggest that oxygen supply by M101 is an important feature in its hepatoprotective effect. This does not exclude that other effects may be part the mechanism. For example, another M101 effect on HepaRG cells might be the down-regulation of pro-inflammatory cytokines and chemokine ligands, or the upregulation of prohealing mediators and immune modulators, as already reported (Batool et al., 2020). Lastly, further studies would be needed to determine whether M101's antioxidant $\mathrm{Cu} / \mathrm{Zn}$ SOD-like properties are involved (Rousselot et al., 2006).

Our present results can be considered with regard to the currently available treatments for Amanita phalloides poisoning. The death rate associated with this poisoning is still high (between 10\% and 20\%), despite the use of antidotes such as penicillins, thioctic acid, $\mathrm{N}$-acetylcysteine, vitamin $\mathrm{C}$, silymarin, and silibinin (Enjalbert et al., 2002; Escudié et al., 2007; Ganzert et al., 2005; Le Daré et al., 2021). The 
fact that none of these compounds are highly effective means that Amanita phalloides poisoning is still a challenging medical emergency. We consider that there are two therapeutic perspectives for the use of M101. Firstly, intravenous infusion can be considered, since biodistribution studies in mice have shown that M101 reaches the liver easily (Le Gall et al., 2014). It has also been reported that silymarin enhances SOD activity, which enables a fall in oxidative stress through the harvesting and recycling of ROS, and thus an overall decrease in tissue inflammation and cell death. We suggest that M101's SOD-like activity (alone or in combination with currently available antidotes) might be of therapeutic value for promoting hepatocyte survival (Wellington and Jarvis, 2001). Secondly, M101 could be added to an organ preservation solution if liver transplantation is required after Amanita phalloides poisoning. Although this requirement is infrequent, there are case reports of reintoxication of the newly transplanted graft - jeopardizing the clinical outcome (Kucuk et al., 2005). Furthermore, this hemoglobin was developed first in the organ preservation indication, and its good safety profile has been reported in many indications - including liver transplant (Alix et al., 2020; Glorion et al., 2017; Mallet et al., 2014; Teh et al., 2017; Thuillier et al., 2019). Lastly, Ye et al. (2018) reported that liver transplantation was considered to be the only approach for guaranteeing survival in Amanita phalloides poisoning with fulminant hepatic failure (Ye and Liu, 2018). Our present data suggest that a liver transplant incubated with M101 might offer a better outcome in this context.

In conclusion, the present study is the first to have demonstrated the value of M101 for reducing amanitin-induced toxicity in an in vitro hepatic cell model. Further studies are needed to explore the exact mechanisms involved in M101's hepatoprotective effects. In vivo studies would be of particular interest. 


\section{Contributors}

217 All authors contributed significantly, and all authors agree with the content of the manuscript:

218 Conception/Design: Brendan Le Daré, Thomas Gicquel, Vincent Lagente

219 Collection and/or assembly of data: Brendan Le Daré, Thomas Gicquel, Vincent Lagente, Nessrine

Bellamri, Pierre-Jean Ferron, Catherine Ribault

221

Data analysis and interpretation: All authors

222

223

224

225

Manuscript writing: All authors

Final approval of manuscript: All authors.

\section{Conflict of Interest Statement:}

Franck Zal is the founder of and holds stock in Hemarina, the company that produces M101 and commercializes it as $\mathrm{HEMO}_{2} \mathrm{life}^{\circledR}$. Eric Delpy is an employee of Hemarina. The other authors declare that they have no conflicts of interest.

\section{Fundings}

This research did not receive any specific grant from funding agencies in the public, commercial, or notfor-profit sectors.

\section{REFERENCES}

Ali, A., Watanabe, Y., Galasso, M., Watanabe, T., Chen, M., Fan, E., Brochard, L., Ramadan, K., Ribeiro, R.V.P., Stansfield, W., Gokhale, H., Gazzalle, A., Waddell, T., Liu, M., Keshavjee, S., Cypel, M., 2020. An extracellular oxygen carrier during prolonged pulmonary preservation improves post-transplant lung function. J. Heart Lung Transplant. Off. Publ. Int. Soc. Heart Transplant. 39, 595-603. https://doi.org/10.1016/j.healun.2020.03.027

Alix, P., Val-Laillet, D., Turlin, B., Ben Mosbah, I., Burel, A., Bobillier, E., Bendavid, C., Delpy, E., Zal, F., Corlu, A., Boudjema, K., 2020. Adding the oxygen carrier M101 to a cold-storage solution could be an alternative to HOPE for liver graft preservation. JHEP Rep. 2, 100119. https://doi.org/10.1016/j.jhepr.2020.100119

Aninat, C., Piton, A., Glaise, D., Le Charpentier, T., Langouët, S., Morel, F., Guguen-Guillouzo, C., Guillouzo, A., 2006. Expression of cytochromes P450, conjugating enzymes and nuclear receptors in human hepatoma HepaRG cells. Drug Metab. Dispos. Biol. Fate Chem. 34, 7583. https://doi.org/10.1124/dmd.105.006759

Arima, Y., Nitta, M., Kuninaka, S., Zhang, D., Fujiwara, T., Taya, Y., Nakao, M., Saya, H., 2005. Transcriptional Blockade Induces p53-dependent Apoptosis Associated with Translocation of 
p53 to Mitochondria. J. Biol. Chem. 280, 19166-19176. https://doi.org/10.1074/jbc.M410691200

Batool, F., Stutz, C., Petit, C., Benkirane-Jessel, N., Delpy, E., Zal, F., Leize-Zal, E., Huck, O., 2020. A therapeutic oxygen carrier isolated from Arenicola marina decreased P. gingivalis induced inflammation and tissue destruction. Sci. Rep. 10, 14745. https://doi.org/10.1038/s41598-02071593-8

Cerec, V., Glaise, D., Garnier, D., Morosan, S., Turlin, B., Drenou, B., Gripon, P., Kremsdorf, D., Guguen-Guillouzo, C., Corlu, A., 2007. Transdifferentiation of hepatocyte-like cells from the human hepatoma HepaRG cell line through bipotent progenitor. Hepatology 45, 957-967. https://doi.org/10.1002/hep.21536

DüNdar, Z.D., ErgiN, M., Kilinç, İ., çOlak, T., Oltulu, P., Cander, B., 2017. The role of oxidative stress in $\alpha$-amanitin-induced hepatotoxicityin an experimental mouse model. Turk. J. Med. Sci. 47, 318-325. https://doi.org/10.3906/sag-1503-163

Enjalbert, F., Rapior, S., Nouguier-Soulé, J., Guillon, S., Amouroux, N., Cabot, C., 2002. Treatment of Amatoxin Poisoning: 20-Year Retrospective Analysis. J. Toxicol. Clin. Toxicol. 40, 715-757. https://doi.org/10.1081/CLT-120014646

Escudié, L., Francoz, C., Vinel, J.-P., Moucari, R., Cournot, M., Paradis, V., Sauvanet, A., Belghiti, J., Valla, D., Bernuau, J., Durand, F., 2007. Amanita phalloides poisoning: Reassessment of prognostic factors and indications for emergency liver transplantation. J. Hepatol. 46, 466473. https://doi.org/10.1016/j.jhep.2006.10.013

G. Tsai, A., Intaglietta, M., Sakai, H., Delpy, E., Drieu La Rochelle, C., Rousselot, M., Zal, F., 2012. Microcirculation and NO-CO Studies of a Natural Extracellular Hemoglobin Developed for an Oxygen Therapeutic Carrier. Curr. Drug Discov. Technol. 9, 166-172. https://doi.org/10.2174/157016312802650814

Ganzert, M., Felgenhauer, N., Zilker, T., 2005. Indication of liver transplantation following amatoxin intoxication. J. Hepatol. 42, 202-209. https://doi.org/10.1016/j.jhep.2004.10.023

Garcia, J., Costa, V.M., Carvalho, A., Baptista, P., de Pinho, P.G., de Lourdes Bastos, M., Carvalho, F., 2015. Amanita phalloides poisoning: Mechanisms of toxicity and treatment. Food Chem. Toxicol. 86, 41-55. https://doi.org/10.1016/j.fct.2015.09.008

Glorion, M., Polard, V., Favereau, F., Hauet, T., Zal, F., Fadel, E., Sage, E., 2017. Prevention of ischemia-reperfusion lung injury during static cold preservation by supplementation of standard preservation solution with $\mathrm{HEMO}_{2}$ life ${ }^{\circledR}$ in pig lung transplantation model. Artif. Cells Nanomedicine Biotechnol. 1-8. https://doi.org/10.1080/21691401.2017.1392315

Kaya, E., Yilmaz, I., Sinirlioglu, Z.A., Karahan, S., Bayram, R., Yaykasli, K.O., Colakoglu, S., Saritas, A., Severoglu, Z., 2013. Amanitin and phallotoxin concentration in Amanita phalloides var. alba mushroom. Toxicon 76, 225-233. https://doi.org/10.1016/j.toxicon.2013.10.008

Kucuk, H.F., Karasu, Z., Kilıc, M., Nart, D., 2005. Liver Failure in Transplanted Liver Due to Amanita Falloides. Transplant. Proc. 37, 2224-2226. https://doi.org/10.1016/j.transproceed.2005.03.107

Le Daré, B., Ferron, P.-J., Gicquel, T., 2021. Toxic Effects of Amanitins: Repurposing Toxicities toward New Therapeutics. Toxins 13, 417. https://doi.org/10.3390/toxins 13060417

Le Gall, T., Polard, V., Rousselot, M., Lotte, A., Raouane, M., Lehn, P., Opolon, P., Leize, E., Deutsch, E., Zal, F., Montier, T., 2014. In vivo biodistribution and oxygenation potential of a new generation of oxygen carrier. J. Biotechnol. 187, 1-9. https://doi.org/10.1016/j.jbiotec.2014.07.008

Lemaire, F., Sigrist, S., Delpy, E., Cherfan, J., Peronet, C., Zal, F., Bouzakri, K., Pinget, M., Maillard, E., 2019. Beneficial effects of the novel marine oxygen carrier M101 during cold preservation of rat and human pancreas. J. Cell. Mol. Med. 23, 8025-8034. https://doi.org/10.1111/jcmm.14666

Letschert, K., Faulstich, H., Keller, D., Keppler, D., 2006. Molecular Characterization and Inhibition of Amanitin Uptake into Human Hepatocytes. Toxicol. Sci. 91, 140-149. https://doi.org/10.1093/toxsci/kfj141

Leu, J.I.-J., George, D.L., 2007. Hepatic IGFBP1 is a prosurvival factor that binds to BAK, protects the liver from apoptosis, and antagonizes the proapoptotic actions of p53 at mitochondria. Genes Dev. 21, 3095-3109. https://doi.org/10.1101/gad.1567107 
Ljungman, M., Zhang, F., Chen, F., Rainbow, A.J., McKay, B.C., 1999. Inhibition of RNA polymerase II as a trigger for the p53 response. Oncogene 18, 583-592. https://doi.org/10.1038/sj.onc.1202356

Magdalan, J., Piotrowska, A., Gomułkiewicz, A., Sozański, T., Szeląg, A., Dziegięl, P., 2011. Influence of commonly used clinical antidotes on antioxidant systems in human hepatocyte culture intoxicated with $\alpha$-amanitin. Hum. Exp. Toxicol. 30, 38-43. https://doi.org/10.1177/0960327110368418

Mallet, V., Dutheil, D., Polard, V., Rousselot, M., Leize, E., Hauet, T., Goujon, J.M., Zal, F., 2014. Dose-Ranging Study of the Performance of the Natural Oxygen Transporter HEMO ${ }_{2}$ Life in Organ Preservation: Dose-Ranging Study of the Performance of $\mathrm{HEMO}_{2}$ Life. Artif. Organs 38, 691-701. https://doi.org/10.1111/aor.12307

Rousselot, M., Delpy, E., Drieu La Rochelle, C., Lagente, V., Pirow, R., Rees, J.-F., Hagege, A., Le Guen, D., Hourdez, S., Zal, F., 2006. Arenicola marina extracellular hemoglobin: a new promising blood substitute. Biotechnol. J. 1, 333-345. https://doi.org/10.1002/biot.200500049

Tavassoli, M., Afshari, A., Arsene, A.L., Mégarbane, B., Dumanov, J., Paoliello, M.M.B., Tsatsakis, A., Carvalho, F., Hashemzaei, M., Karimi, G., Rezaee, R., 2019. Toxicological profile of Amanita virosa - A narrative review. Toxicol. Rep. 6, 143-150. https://doi.org/10.1016/j.toxrep.2019.01.002

Teh, E.S., Zal, F., Polard, V., Menasché, P., Chambers, D.J., 2017. HEMO 2 life as a protective additive to Celsior solution for static storage of donor hearts prior to transplantation. Artif. Cells Nanomedicine Biotechnol. 45, 717-722. https://doi.org/10.1080/21691401.2016.1265974

Thuillier, R., Delpy, E., Matillon, X., Kaminski, J., Kasil, A., Soussi, D., Danion, J., Sauvageon, Y., Rod, X., Donatini, G., Barrou, B., Badet, L., Zal, F., Hauet, T., 2019. Preventing acute kidney injury during transplantation: the application of novel oxygen carriers. Expert Opin. Investig. Drugs 28, 643-657. https://doi.org/10.1080/13543784.2019.1628217

Wang, M., Chen, Y., Guo, Z., Yang, C., Qi, J., Fu, Y., Chen, Z., Chen, P., Wang, Y., 2018. Changes in the mitochondrial proteome in human hepatocytes in response to alpha-amanitin hepatotoxicity. Toxicon 156, 34-40. https://doi.org/10.1016/j.toxicon.2018.11.002

Wellington, K., Jarvis, B., 2001. Silymarin: A Review of its Clinical Properties in the Management of Hepatic Disorders: BioDrugs 15, 465-489. https://doi.org/10.2165/00063030-20011507000005

Wieland, T., 2009. The toxic peptides from Amanita mushrooms. Int. J. Pept. Protein Res. 22, 257276. https://doi.org/10.1111/j.1399-3011.1983.tb02093.x

Ye, Y., Liu, Z., 2018. Management of Amanita phalloides poisoning: A literature review and update. J. Crit. Care 46, 17-22. https://doi.org/10.1016/j.jcrc.2018.03.028

Zheleva, A., 2013. Phenoxyl radicals formation might contribute to severe toxicity of mushrooom toxin alpha amanitin - an electron paramagnetic resonance study.

Zheleva, A., Tolekova, A., Zhelev, M., Uzunova, V., Platikanova, M., Gadzheva, V., 2007. Free radical reactions might contribute to severe alpha amanitin hepatotoxicity - A hypothesis. Med. Hypotheses 69, 361-367. https://doi.org/10.1016/j.mehy.2006.10.066 


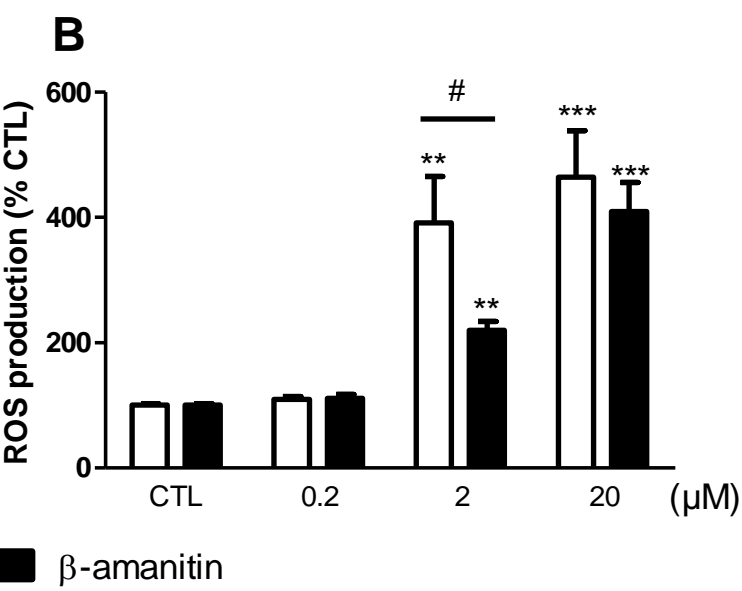

Figure 1: Effect of $\alpha$ - and $\beta$-amanitin on the viability of differentiated hepatocytes. Differentiated

357

358

HepaRG cells were cultured with $\alpha$ - or $\beta$-amanitin $(0.2$ to $20 \mu \mathrm{M})$ or medium for $24 \mathrm{~h}$. Cell viability was measured using an extracellular ATP assay and expressed relative to the value determined after treatment with medium alone (arbitrarily set to 100\%). Levels of mitochondrial ROS $24 \mathrm{~h}$ after amanitin treatment were detected using a MitoSOX $(5 \mu \mathrm{M})$ probe and normalized against the protein content. The data are quoted as the mean \pm SEM from at least three independent experiments performed in triplicate. ** $p<0.01 * * * p<0.001$ : the control condition compared with $\alpha$ - or $\beta$-amanitin at different

\section{concentrations. $\# \mathrm{p}<0.05 \# \# \mathrm{p}<0.01: \alpha$-amanitin compared with $\beta$-amanitin.}


A

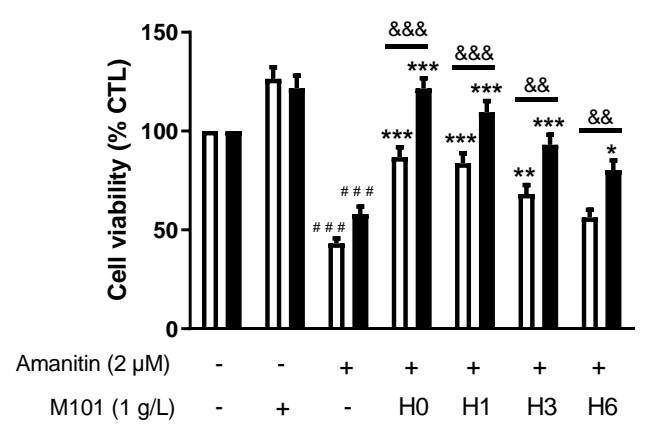

$\square$ a-amanitin

\section{C}

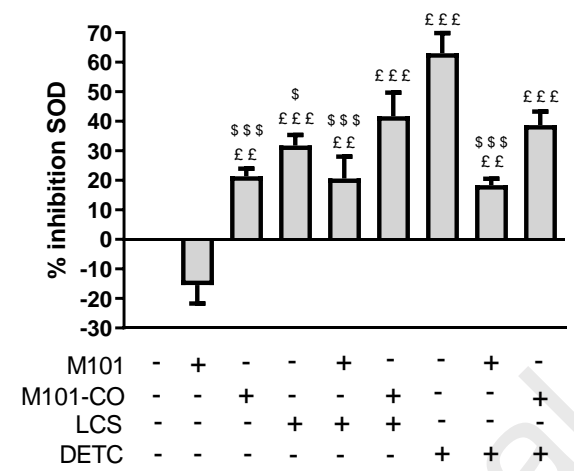

B

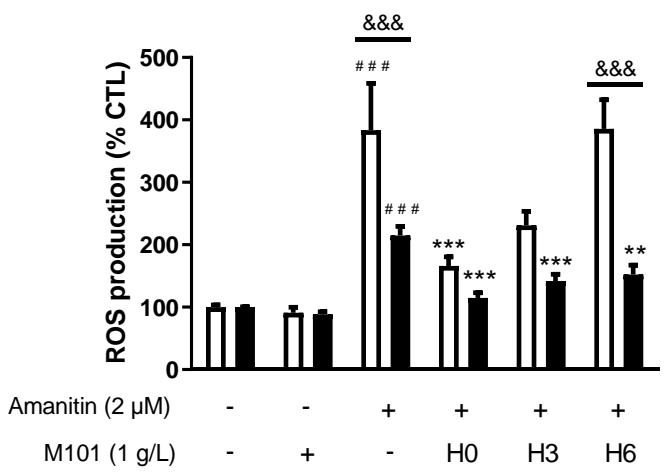

$\beta$-amanitin

D

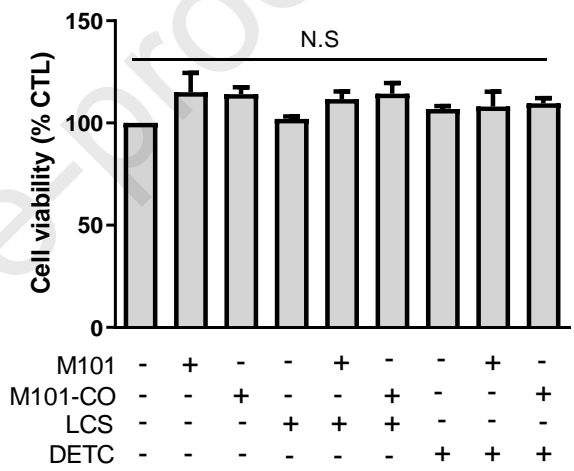

Figure 2: Effect of M101 on amanitin-induced hepatotoxicity. (A and B) Differentiated HepaRG cells were cultured with $\alpha$ - or $\beta$-amanitin $(2 \mu \mathrm{M})$ or medium for $24 \mathrm{~h}$ at $37^{\circ} \mathrm{C}$ and with $5 \% \mathrm{CO}_{2}$ in the absence or presence of M101 (1 g/L) added up to $6 \mathrm{~h}$ after amanitin treatment. (A and D) The viability of differentiated HepaRG cells was measured using an extracellular ATP assay and expressed relative to the value determined after treatment with medium alone (arbitrarily set to 100\%). (B) Levels of mitochondrial ROS $24 \mathrm{~h}$ after amanitin treatment were detected using a MitoSOX $(5 \mu \mathrm{M})$ probe and normalized against the protein content. (C) SOD activity in the presence of M101 (1 g/L), M101-CO (1 $\mathrm{g} / \mathrm{L})$, DETC $(100 \mu \mathrm{M})$ and/or LCS $(10 \mu \mathrm{M})$ was determined using SOD assay kit and expressed relative to the value determined after treatment with medium alone (arbitrary set to $0 \%$ ). The data are quoted as the mean \pm SEM from three independent experiments performed in triplicate. ${ }^{\# \#} p<0.01{ }^{\# \# \#} p<0.001$ : Control condition compared with $\alpha$ - or $\beta$-amanitin alone. ${ }^{*} p<0.05 * * p<0.01 * * * p<0.001$ : $\alpha$ - or $\beta$ amanitin alone compared with $\alpha$ - or $\beta$-amanitin + M101 added at a different time point $(\mathrm{H} 0, \mathrm{H} 1, \mathrm{H} 3$, 
388 H6). \&\& $p<0.01 \& \& \& p<0.001: \alpha$-amanitin compared with $\beta$-amanitin. $\$ p<0.05 \$ \$ \$ p<0.001$ :

389 in comparison with DECT alone. $£ £ \mathrm{p}<0.01 £ £ £ \mathrm{p}<0.001$ : in comparison with M101 alone.

390

391 


\section{HIGHLIGHTS}

- $\alpha$ - and $\beta$-amanitin lead to cell death and mitochondrial reactive oxygen species production in differentiated HepaRG cells.

- M101 is effective in reducing amanitin-induced cell death and mitochondrial reactive oxygen species production in vitro.

- M101 might be effective in reducing amanitin-induced hepatotoxicity and may have potential for therapeutic development. 
This material is the authors' own original work, which has not been previously published elsewhere. 


\section{Declaration of interests}

The authors declare that they have no known competing financial interests or personal relationships that could have appeared to influence the work reported in this paper.

$\bigotimes$ The authors declare the following financial interests/personal relationships which may be considered as potential competing interests:

Franck Zal is the founder of and holds stock in Hemarina, the company that produces M101 and commercializes it as $\mathrm{HEMO}_{2}$ life. Eric Delpy is an employee of Hemarina. The other authors declare that they have no conflicts of interest. 